DOI: 10.17707/AgricultForest.65.4.15

\author{
Mersida JANDRIĆ, Željko SAVIĆ ${ }^{1}$
}

\title{
INFLUENCE OF MILK ON THE CONTENT AND CHANGES OF MILK FAT DURING PRODUCTION OF SJENIČKI WHITE CHEESE
}

\begin{abstract}
SUMMARY
The quality and overall values of the cheese depend on the type and quality of milk. Milk fat is the most important parameters of quality which determines randman, consistency, rheological characteristics and sensory properties of cheese dough. The studies aimed to determine the significance of milk type for the percentage of milk fat content after cheese making, changes during ripening, as well as the content of mature cheeses for a 45-day ripening period when it comes to Sjenica cheese of industrial production. Studies have shown that the milk fat content in cottage cheeses were for cow milk cheese $21.33 \%$ and $23: 43 \%$ for sheep milk cheese. During ripening, the milk fat content in both kinds of cheese for the whole period of ripening steadily increased. After 45-day period of ripening cow milk cheese had an average content of $25.66 \%$, and sheep milk cheese had $29.36 \%$ milk fat.

At the end of the ripening period of 45 days average content of milk fat was in cow milk cheese $25.66 \%$ and $29.36 \%$ in sheep milk cheese. Dynamics of milk fat in dry matter had a different trend. In cow milk cheese was recorded a decrease in the first 30 days and a slight increase in the last 15 days. Sheep milk cheese had a trend of balanced increase for the entire period of ripening. The content of milk fat in dry matter (MF in DM) in mature kinds of cheese in average was $51.07 \%$ in cow milk cheese and $52.72 \%$ in sheep milk cheese. These results showed that the cheese had a high content of fat in dry matter and belong to the group of full-fat kind of cheese.
\end{abstract}

Key words: Sjenički cheese, milk fat, ripening.

\section{INTRODUCTION}

Sjenički cheese is one of the famous white brined cheese in the Republic of Serbia. Center of the production are mountain plateau, with a rich, healthy and high-quality natural meadows and pastures on the Pester plateau that surround the town Sjenica. It is produced by the indigenous technology on individual farms, and now more and more in industrial conditions. The raw material for the production is fresh whole fat cow's and sheep's milk without the application of heat treatment in process of making cheese.

The quality and overall value of the cheese depends on chemical composition and quality of milk, whereby a fat content is of particular

\footnotetext{
${ }^{1}$ Mersida Jandrić *(corresponding author: mersida.jandric@hotmail.com), Željko Savić, University of Pristina, Faculty of Agriculture, Lesak, SERBIA

Notes: The authors declare that they have no conflicts of interest. Authorship Form signed online.
} 
importance. The fat content of milk depends on the species, breed, diet, lactation, etc. Sheep's milk has high values of chemical components, and it is the best raw material for the production of cheese, because it gives twice higher randman than cow's milk. Milk fat is one of the most valuable parameters of the chemical composition of milk on which depend the quality and the overall value of the cheese.

The content of milk fat in cheese affects on its energetic and nutritional value, chemical composition and rheological characteristics, respectively, its structure and consistency. Milk fat in cheese is mainly in solid, aggregate state and it is distributed in a protein matrix.

Together with water, even though to a less extent, it is the carrier of viscous properties of the cheese. The milk fat content is determined by the size of fat droplets in milk, standardization, coagulation and curd processing (Bringe and Kinsella 1986; Fox and Cogan 2000; Lopez et al., 1998).

Djordjević (1987) states that the size of fat droplets affects the retention of fat in the cheese lump and its transition into the whey. If fat droplets are larger and if process of making cheese lasts longer, the transition of milk fat into the whey is greater during the curd processing.

The main function of fat is reflected in its contribution to the sensory properties of cheese. The milk fat, due to the high share of low and medium fat acids, as well as the characteristic melting temperature, which is close to the temperature of a human body, has a very pronounced effect on the taste and smell of cheese. Therefore, the cheese with high fat content is characterized by a fuller taste and smell (Puđa, 2009).

Milk fat, with proteins, represents the predominant part of the dry matter of cheese. Changes in milk fat during ripening are at much lower level in response to changes of proteins. A smaller volume of fat change is the result of very limited accessibility of substrates. The milk fat during cheese production retains the shape of fat droplets, the form in which the milk fat is originally present in the milk. During cheese ripening membrane of fat droplets constitutes a sort of protection to lipids content, so that the lipases presented in the cheese mass significantly come more difficult into contact with the substrate. The decomposition of fat by enzymes lipase is done during the ripening process, which means, hydrolysis of the triglycerides to free fat acids and small amounts of diglycerides and monoglycerides is occurred. It is generally accepted that the lipase is largely responsible for the release of free fat acids, which contain more than four carbon (C-4) atoms. The free fat acids affect the taste of the cheese, and serve as a substrate for the formation of other compounds such as: alcohols, estri, aldehydes, ketones, et al. (Fox et al., 1993; and Fenelon Guinee, 2000).

Milk fat and its degradation products influence the formation of the sensory properties of the cheese. However, in terms of the uncontrolled maturation, changes in free fat acids can cause the appearance of rancid taste (Wilkinson, 1990). 


\section{MATERIAL AND METHODS}

The experiments with the industrial production of cheese are made in the dairy "Pester" in Sjenica, Republic of Serbia. The both types of cheese are made from raw whole cow's and sheep's milk. Preparation of milk included primary treatment (squeezing- filtering) and reheating at a temperature, equal to the temperature needed for the process of making cheese, of $32{ }^{\circ} \mathrm{C}$. Milk coagulation lasted $50 \mathrm{~min}$. Curd was cut into cubes of $5 \times 5 \mathrm{~cm}$. Whey separation and the formation of curd was carried out by filtration in the course of $1.5 \mathrm{~h}$. The cheese was sliced into slices of $10 \times 10 \mathrm{~cm}$. The research was aimed to determine the content of fat and fat in dry matter (MF in DM) in cheese after the preparation ( $1^{\text {st }}$ day), and then to monitor their changes after 15,30 and 45 days of ripening which was optimal ripening period.

Cheese analysis was conducted in the chemical laboratory of the Veterinary specialist institute, by the following methods:

-Determination of fat percentage by Van-Gulik Acidobutyrometric method (Carić et al., 2000).

- The both types of cheese were made in 5 repetitions, and the total sample was 10 .

Rate of statistical significance was carried out over a difference of arithmetic means and measures of variations, standard deviation (SD) and coefficient of variation (CV). Student's t-test was used to test the difference of means (Stanković et al., 1989).

\section{Determination of \% fat by Van Gulik method}

Apparatus and accessories: Analytical balance; Butyrometer for cheese; Automatic pipette $10 \mathrm{ml}$; Gerber's centrifuge; Water bath, $\mathrm{t}=65-70{ }^{\circ} \mathrm{C}$.

Reagents: sulfuric acid; Amyl alcohol.

Procedure: In a butyrometer glass $3 \mathrm{~g}$ cheese sample is weighed. We put the glass in butyrometer, and through upper opening of butyrometer, we pour sulfuric acid so that the acid level covers the contents of the cup. We close the butyrometer, shake it strongly and place it in a water bath temperature of 65-70 ${ }^{0} \mathrm{C}$, with intent of cheese dissolution. It is needed to jumble the content of butyrometer every $15 \mathrm{~min}$. Agitation of butyrometer is steadily growing until the complete dissolution of cheese, whereby the liquid gets darkly violet color. When the sample is dissolved, butyrometer is removed from the bath and using automatic pipette we add $1 \mathrm{ml}$ amilo alcohol, then we well shake the content and add sulfuric acid approximately to the upper line of the scale. Shaken butyrometer is kept in a water bath for $5 \mathrm{~min}$ at a temperature of $65^{\circ} \mathrm{C}$. Then we clean off the butyrometer and put in a Gerber's centrifuge. Centrifuge it for $5 \mathrm{~min}$, remove the butyrometer and place it with facing down lower stoppers in a water bath of $65{ }^{\circ} \mathrm{C}$, for 3-5 min.

Isolated fat in dried part of butyrometer is the amount of fat in weight percentages directly seen on a scale of butyrometer. 


\section{RESULTS AND DISCUSSION}

Milk fat is an important nutritive component of milk and cheese and greatly contributes to the formation of specific sensory and functional properties of the cheese. Milk fat which is incorporated into a protein matrix, which presents the base of cheese structure, provides a so-called "Smooth taste of whole fat milk cheese“ (Miočinović, 2013).

Research results related to the dynamics of fat during cheese ripening are given in Table 1.

Table 1. Dynamics of fat during cheese ripening in \%

\begin{tabular}{|l|l|r|r|r|r|}
\hline Cheese type & Parameters & \multicolumn{4}{|c|}{ Ripening period (days) } \\
\cline { 2 - 6 } & & 1 & 15 & \multicolumn{1}{c|}{30} & \multicolumn{1}{c|}{45} \\
\hline \multirow{4}{*}{$\begin{array}{l}\text { Cow's milk } \\
\text { cheese }\end{array}$} & Min & 20.43 & 19.90 & 18.70 & 21.39 \\
\cline { 2 - 6 } & Max & 22.10 & 24.71 & 27.34 & 27.63 \\
\cline { 2 - 6 } & $\bar{x}=(\mathrm{n}=5)$ & 21.33 & 22.26 & 24.29 & 25.66 \\
\cline { 2 - 6 } & $\mathrm{Sd}$ & 0.60 & 1.55 & 2.94 & 2.28 \\
\cline { 2 - 6 } & $\mathrm{Cv} \%$ & 2.83 & 6.96 & 12.10 & 8.91 \\
\hline \multirow{4}{*}{$\begin{array}{l}\text { Sheep's milk } \\
\text { cheese }\end{array}$} & Min & 22.03 & 24.76 & 26.62 & 27.63 \\
\cline { 2 - 6 } & Max & 24.71 & 26.25 & 30.78 & 29.85 \\
\cline { 2 - 6 } & $\bar{x}=(\mathrm{n}=5)$ & 23.43 & 25.94 & 28.31 & 29.36 \\
\cline { 2 - 6 } & $\mathrm{Sd}$ & 0.87 & 0.76 & 1.77 & 1.33 \\
\cline { 2 - 6 } & $\mathrm{Cv} \%$ & 3.71 & 2.95 & 6.26 & 4.50 \\
\hline
\end{tabular}

Testing the significance of arithmetic means

\begin{tabular}{|c|c|c|}
\hline Ripening period-days & t-calculated & $\mathrm{X}_{1}-\mathrm{X}_{2}$ \\
\hline 1 & 4.46 & $2.10^{* *}$ \\
\hline 15 & 4.77 & $3.68^{* *}$ \\
\hline 30 & 2.62 & $4.02^{*}$ \\
\hline 45 & 3.13 & $3.70^{* *}$ \\
\hline
\end{tabular}

The theoretical values of the „t“ arrangement refer to the number of degrees of freedom (df) 8 and are: $\mathrm{p}<0.05=2.179 ; \mathrm{p}<0.01=3.055$

At the beginning of ripening cow's milk cheese had an average milk fat of 21:33\%, and sheep's milk cheese 23:43\%. The analysis of the results showed that these differences were statistically significant. Differences in fat content are the result of different water content, as well as the raw material that is used for making cheese.

As a ripening period develops, an increasing content of milk fat for the entire period of maturity in both types of cheese is noticed, whereby this increase was even.

After 15-days of ripening average increase of milk fat in cow's milk cheese amounted $0.93 \%$ and in sheep's milk cheese $2: 51 \%$, so that the cow's milk cheese had an average of 22:26\% of milk fat and sheep's milk cheese 
25.94\%. Processing of the results showed that the differences between the both types of cheese were highly significant.

Table 2. Dynamic of milk fat in dry mater (MF in DM) during ripening period in $\%$

\begin{tabular}{|l|l|r|r|r|r|}
\hline \multirow{3}{*}{$\begin{array}{c}\text { Cheese } \\
\text { type }\end{array}$} & Parameters & \multicolumn{4}{|c|}{ Ripening period (days) } \\
\cline { 2 - 6 } & & 1 & 15 & \multicolumn{1}{|c|}{30} & \multicolumn{1}{c|}{45} \\
\hline \multirow{4}{*}{$\begin{array}{l}\text { Cow's milk } \\
\text { cheese }\end{array}$} & $\min$ & 49.37 & 47.29 & 42.58 & 45.94 \\
\cline { 2 - 6 } & $\max$ & 52.88 & 50.94 & 50.98 & 53.52 \\
\cline { 2 - 6 } & $\bar{x}=(\mathrm{n}=5)$ & 51.76 & 49.16 & 48.33 & 51.07 \\
\cline { 2 - 6 } & $\mathrm{Sd}$ & 1.26 & 1.42 & 2.94 & 1.64 \\
\cline { 2 - 6 } & $\mathrm{Cv} \%$ & 2.44 & 2.90 & 6.09 & 3.22 \\
\hline \multirow{4}{*}{$\begin{array}{l}\text { Sheep's } \\
\text { milk } \\
\text { cheese }\end{array}$} & $\min$ & 47.81 & 49.01 & 52.22 & 49.11 \\
\cline { 2 - 6 } & $\max$ & 51.50 & 52.20 & 54.64 & 55.33 \\
\cline { 2 - 6 } & $\bar{x}=(\mathrm{n}=5)$ & 49.44 & 50.46 & 51.21 & 52.72 \\
\cline { 2 - 6 } & $\mathrm{Sd}$ & 1.26 & 1.35 & 2.73 & 2.66 \\
\cline { 2 - 6 } & $\mathrm{Cv} \%$ & 2.55 & 2.68 & 5.34 & 5.04 \\
\hline
\end{tabular}

Testing the significance of arithmetic means

\begin{tabular}{|c|c|c|}
\hline Ripening period-days & t-calculated & $\mathrm{X}_{1}-\mathrm{X}_{2}$ \\
\hline 1 & 2.91 & $2.32^{*}$ \\
\hline 15 & 1.48 & 1.30 \\
\hline 30 & 1.60 & 2.88 \\
\hline 45 & 1.18 & 1.65 \\
\hline
\end{tabular}

The theoretical values of the "t“ arrangement refer to the number of degrees of freedom (df) 8 and are: $\mathrm{p}<0.05=2.179 ; \mathrm{p}<0.01=3.055$

The fat content trend increasing has continued in the period of 15-30 days of ripening. This increase in cow's milk cheese was 2:03\%, and 2:37\% in sheep's milk cheese. After 30 days of ripening cow's milk cheese is the average had $24.29 \%$ of milk fat and sheep's milk cheese had $28.31 \%$ of milk fat. Analysis of the data showed that the differences between the cheeses were statistically significant.

During the last 15 days of ripening, a further increase of fat content was observed. After a set period of ripening, the average content of milk fat was $25.66 \%$ in cow's milk cheese and $29.36 \%$ in sheep's milk cheese.

Analysis of the data resulted in statistically highly significant differences among both kinds of cheese.

If we compare both types of the cheese at the beginning and end of the ripening period, we can conclude that the milk fat content increased in cow's milk cheese for 4:33\% and 5.93\% for sheep's milk cheese.

If we analyze the correlation between fat content and moisture content of the cheese, it leads to the conclusion that the reduction in moisture is in 
proportion to the increase of milk fat content. Proof of this is sheep cheese, which contains the most milk fat, and contains a minimum of moisture.

The obtained results of milk fat content are in accordance with the results of similar types of cheese in this group, and which state the following authors: fat cheese 26.32\%, Pljevaljski cheese 25.44\% Polimsko-Vasojevićki 29.38\% Polimsko-Sjenicki 24.92\% (Dozet et al. 1996); Domiati 22.75\% (Abd El Salam 1993); White cheese-slice 19.87\% (Živić, 1989); Homoljski 28.42\% (Jovanovic et al., 2004); Sjenički 27.22\%, 27.70\% Zlatarski (Maćej et al., 2006); Sjenički cheese 26.38\%, Sjenički type cheese 24.63\% (Savić, 2011); PolimskoVasojevićki 29.85\% (Konotar, 2006).

Savic et al., (2016) state that the basis of curd structure is composed of proteins, while milk fat plays a filler role and is incorporated into the curd network and contributes to the soft consistency of Sjenica cheese and good sensory properties.

During the cheese ripening, different processes occur, some of which lead to the concentration of milk fat in dry matter. The fat content in dry matter depends on the amount of salt $(\mathrm{NaCl})$, because the salt drawing water from the cheese increases dry matter. Among other processes that affect the concentration of milk fat in dry matter, it includes also the transition of soluble nitrogen matter of cheese into brine for ripening, as well as the decline of the salt concentration in the cheese. Results in the content and dynamics of milk fat in dry matter (MF in DM) are given in Table 2.

Based on these results, it can be seen that dynamics of fat in dry matter had a trend of balanced increase for the entire fixed period of maturity of $49.44 \%$ to $52.72 \%$ in sheep's milk cheese. In cow's milk cheese it is recorded a declining trend for the period 1-30 day maturity from $51.76 \%$ to $48.33 \%$, and the increase in the last 15 days of ripening for $51.07 \%$.

At the end of the set period of ripening, the milk fat content in the dry matter, in average was $51.07 \%$ in cow's milk cheese and 52.72\% in sheep's milk cheese. Processing of the results showed that the differences between two types of cheese were not statistically significant. Bearing in mind the fact that fresh whole milk is used for making cheese, therefore cheese is characterized by a high content of fat in dry matter $(51.07 \%, 52.72)$ due to which belong to the group of full-fat cheese.

\section{CONCLUSION}

Milk fat is one of the most valuable parameters of chemical composition and quality of the milk, and the physical properties, chemical composition of curd, structure and randman of cheese production depend on it.

Milk fat content in cheese effects on its energetic and nutritional value, chemical composition and rheological properties and on its viscosities consistency structure. The type of fat cheese has softer coexistence, while the cheese with lower milk fat has tougher dough and firmer consistency. 
Basic function of fat is reflected in her contribution, formation of sensory and functional properties of cheese, and lower and middle fat acids. Milk fat as a very pronounced effect on the taste and smell of cheese, which is a characteristic of sheep's milk cheese.

Cheese is characterized by a high content of fat and fat in dry matter (MF in DM), since the raw material for making cheese was whole cow's and sheep's milk. On the basis of fat content in dry matter (51.07\% and 52.72\%), all types belong to the group of full-fat types of cheese.

\section{REFERENCES}

Abd El Salam, M. H. Alichanidis E. Zerfiridis, GK (1993): Domiati and Feta Cheese Type. PF Fox (Editor): Cheese; Chemistri, physics and microbiology, London.

Bring, N.A. and Kinsella, J. E. (1986): Effect of calcium chloride on Chymosininitiated coagulation of casein micelles. J. Dairy Res. 53 (3), 371-379.

Carić, M.; Milanović, S.; Vučelja, D. (2000): The Standard Methods of Analysis of Milk and Dairy Products, Faculty of Technology, Novi Sad

Dozet, N .; Adzić, N.; Stanišić, M .; Živić, N. (1996): Indigenous Dairy Products, Agricultural Institute, Podgorica, SILMIR, Belgrade

Đorđević, J. (1987): Milk. Scientific Book, Belgrade

Fenelon, MA and Guinee, TP (2000): Flavour development in low-fat cheese. Cheese symposium. Ed.by Cogan, TM, McSweeney, P.L.H. and Guinee, TP, Moorepark, 31-42.

Fox, PF, Leo, J. McSweeney, P.L.H. and Wallace, J. (1993): Biocemistry of cheese ripening and Cheese: Chemistry, physics and microbiology. Volume 1. General aspects. Second edition Chapter 10, 389-438. Ed.by Fox, PF:, Chapman \& Hall, London and New York.

Fox, PF and Cogan, TM (2000): Cheese: scientific highlights of the 20thcentury. $6^{\text {th }}$ Cheese symposium. Ed. by Cogan, TM, McSweeney, PLHandGuinee, TP, MOOREPARK, 83-121.

Jovanović, S., Maćej, O., Barać, M. (2004): Changes during ripening of Svrljiški and Homoljski cheese, Biotechnology in animal husbandry, Vol. 20 (12), 109-117

Konatar, Z. Dozet, N. (2006): Polimsko-Vasojević cheese-indigenous technology. Proceedings of a symposium, "Milk and milk products," Tara 6-10. April

Lopez, MB, Lomholt, SB and Qvist, CB (1998) Rheological properties and cutting time of rennet gels. Effect of $\mathrm{pH}$ and enzyme concentration. Ind. Dairy J. 8 (4), 289-293.

Maćej, A.; Dozet, N.; Jovanović, S. (2006): Characteristics of Indigenous Production of Sjenica, Homoljski, Zlatarski and Svrljiški white cheese, Monograph "Indigenous White Cheese in Brine" Editors Maćej, O. And Dozet, N. 33-65, Faculty of Agriculture, Beograd 
Miočinović, J. (2013): Technology of milk, Practicum, Faculty of Agriculture, University of Belgrade

Puđa, P. (2009): Technology of milk and cheese making, Faculty of Agriculture, Belgrade

Savić. Ž. (2011): Changes of Nitrogen Compounds during Ripening of Sjenički Cheese and Cheese Type of Sjenički, Doctoral dissertation, Faculty of Agriculture, University of Priština

Savić, Ž., Maćej, O., Drašković, N., Milošević, B. (2016): Influence of milk on the content and total protein changes during ripening white cheese in industrial production, Journals „Agriculture\&Forestry”, Vol. 62 Issue 2:145-152, DOI:1017707/Agricult Forest. 62.2.113, Biotehnical Faculty of the University of Montenegro

Stanković, J.; Ralević, N.; Ljubanović-Ralević, I. (1989): Statistics with Applications in Agriculture, Modern Administration, Belgrade

Wilkinson, MG (1990): Acceleration of cheese ripening. $2^{\text {nd }}$ symposium Cheese. Ed. By Cogan, TM MOOREPARK, 111-119.

Živić, N. (1989): Energy value and quality of milk and dairy products from the area of Niš region, Doctoral dissertation, Faculty of Agriculture, Sarajevo. 